\title{
Situating Knowledge about North Korea: Tracing Mainstream Publications on a Topic in International Relations
}

\author{
Max Nurnus and Daniel Clausen
}

\begin{abstract}
How does mainstream knowledge on a topic develop? This study looks at publications in leading International Relations (IR) journals over the past 25 years to examine who publishes what on the issue of North Korea. Of particular interest are the countries where the authors work and where they received their education. This study also examines the citations of these mainstream articles, the institutional origin of their authors and the languages the articles were written in to see which kinds of research articles influence mainstream articles. The study then examines the theoretical makeup of these mainstream articles in order to understand the range of theoretical perspectives. Corresponding with literature that examines the discipline of IR as a whole, the study finds that mainstream scholarship on North Korea is mostly dominated by scholars working and educated in the US with noticeable contributions from South Korea and some scholars from other Western countries as well as the Asia Pacific. The study also finds that academic articles written in languages other than English play virtually no part in the mainstream IR discourse on North Korea. In terms of theory and method, most mainstream articles fall within a relatively narrow range that spans soft-rationalism and non-postmodern constructivism. These results show that patterns of American and European dominance in the discipline of IR as a whole are also visible in the mainstream discourse on North Korea, and that this discourse does not engage with journal publications written in languages other than English.
\end{abstract}

Key Words: North Korea, international relations scholarship, post-western IR, geography of knowledge

$\mathrm{I}$ t has become common to refer to International Relations (IR) as first an American social science, then a European and Western one, and then only

*Max Nurnus (MNurnus@gmail.com) is a PhD student at the Graduate School of International Studies of Seoul National University and currently a Fulbright Visiting Researcher at the Mershon Center for International Security Studies at Ohio State University.

**Daniel Clausen (daniellclausen@gmail.com) is a graduate of Florida International University's $\mathrm{PhD}$ program in International Relations. His research has been published in Asian Politics and Policy, e-IR, Electronic Journal of Contemporary Japanese Studies and Culture and Conflict Review, among other publications.

We are thankful for comments from Bill Demsar, Alan van Beek, Sohyun Yim and Eunyoung Cho. Any errors or omissions are, of course, the responsibility of the authors.

The Korean J ournal of International Studies Vol.13-3 (December 2015), 513-534.

http://dx.doi.org/10.14731/kjis.2015.12.13.3.513

(c) 2015 The Korean Association of International Studies 
sometimes an academic field that reaches to other parts of the world (Hellmann 2011; Hoffmann 1977; Tickner 2013; Wæver 1998). When the subject matter does reach other parts of the world, there is no guarantee that other parts of the world can reach back (Tickner 2013; UNESCO 2010). Thus, while IR scholarship crafted in America and other Western countries has had a substantial influence on IR in other countries, those countries have not had a substantial influence on countries in the West.

Given a thriving literature that examines this degree of "internationalness" of the IR discipline, the location of its production and the level of inclusiveness to various voices, it may be fruitful to extend this conversation to specific topics and sub-disciplines within the larger field of IR. This study looks at one topic in particular - North Korea - to understand who impacts the discourse on this topic. Through an examination of the leading IR journals we will determine who impacts the discourse, where and in what languages the sources these authors draw from were produced, and examine the relative national diversity of contributors to this subfield. In addition, the study will also examine the various theories and methods that underpin mainstream knowledge on the topic. ${ }^{1}$ The guiding question of this study is whether the patterns of dominance by authors from certain geographic regions in mainstream IR journals are also visible when focusing on a region-specific topic - or whether scholars situated within the respective region play a more pronounced role in this case.

The discourse surrounding North Korea in IR journals is of particular interest because of the country's importance to academic communities in diverse geographic regions. For the Asia Pacific region, North Korea is a country of relevance as a perceived security threat to South Korea and Japan, as a partner of dubious value for China and as a source of potential regional and international instability. From the Western, and especially American perspective, North Korea is important because of US ambitions to maintain regional stability, the US security alliance with South Korea and the presence of some 30,00o US troops on the Korean peninsula. One may therefore assume that North Korea is of interest both to Western as well as non-Western regional academic communities. Nevertheless, as past studies have shown (Alatas 2003; Hellmann 2011; UNESCO 2010), interest in a topic is not the only driver of IR scholarly production in mainstream journals. The varying capacities and histories of IR programs in different

\footnotetext{
${ }^{1}$ With the term "mainstream" we refer to the most-widely cited journals in the field of International Relations. As, for example, the 2012 TRIP survey shows, they are influential across the discipline and beyond geographic as well as intra-disciplinary boundaries (see Maliniak et al. 2012, $52)$.
} 
regions also impact who produces what scholarship on a subject. For this reason, examining the influence of scholars from various regions on the topic of North Korea will help us understand better how IR as a discipline functions and the possible impact of scholarly means of production on the discourse in one topic area.

\section{LITERATURE REVIEW: PATTERNS OF PRODUCTION AND CONSUMPTION IN THE FIELD OF IR}

Over the years, IR has become an increasingly reflective discipline, critically examining its own origins and disciplinary practices. Numerous studies have examined patterns of publication in top IR journals (Wæever 1998), the level and degree of participation by countries outside the West (Hellmann 2011; Tickner 2013; Tickner and Blaney 2009; Wæver 1998), the relative influence of Western and non-Western forms of IR on one another (Bilgin 2008; Tickner 2013; Tickner and Blaney 2009), the composition of reading lists in graduate programs (Hagmann and Biersteker 2012) and the prevalence of various theoretical views in journal articles and their impact on the discipline (Smith 2000; Wæver 1998). Other authors have focused on the IR practices of different geographic regions, for example East Asia (Inoguchi 2009), South East Asia (Tan 2009) and the African continent (Ofuho 2009). Many of these studies are driven by the normative goal of pluralizing the discipline and opening up spaces for non-Western voices and indeed a post-Western IR theory (Acharya and Buzan 2007; Bilgin 2008; Ikeda 2010).

A key aspect of this literature is a critical attitude towards the very American and Euro-centricism of what is supposed to be an international discipline. Typically, studies have focused on the two pillars of academic production: peer reviewed journal articles and presentations made at the International Studies Association (ISA), IR's main professional organization. Aydinli and Mathews (2000), for example, using a quantitative study of top-ranked IR journals, found that Western contributions far outweighed contributions by countries outside the West, and that even among the contributions from the West, those from the United States dominated. The only journals that did not follow this pattern were journals published in Europe (where Europeans tended to dominate), and in semi-periphery countries such as India and Russia, where non-Western contributions were more pronounced. This led Aydinli and Mathews to argue that IR is very much a parochial discipline, with Americans dominating top-tier journals in their own country and IR scholars elsewhere choosing other markets. 
Hellmann (2011), following the lead of prior articles on the IR discipline, conducted a quantitative study of participation in ISA conferences, and came up with similar findings. He found that, despite some modest improvements in internationalizing the organization's participation, it still remained dominated by American scholars. He writes that "[ISA] has been quite supportive of efforts to build up professional structures of academic communication beyond it. Yet despite these efforts, ISA conventions - one of the premier sites of intellectual exchange about IR on the global stage - have largely remained intra-Western scholarly exchanges" (Ibid., 1301). His analysis of conference participation finds that:

"[even though] a systematic analysis of attendance patterns at the ISA conventions in Toronto (1997), Portland (2003), and New York (2009), based on the institutional origin of the respective scholars attending, shows a noteworthy increase of European Union-European scholars (16\% in 1997, $15 \%$ in 2003, and $25 \%$ in 2009) relative to North American scholars (United States plus Canada: $76 \%$ in $1997,74 \%$ in 2003, and 62\% in 2009), there was essentially no change if one compared attendance along a Western versus non-Western distinction” (Ibid., 1301).

Perhaps some of the best research on the relative balance of contributions from different areas of the world comes from the UNESCO 2010 World Social Science Report. Though the report evaluates the social sciences as a whole, it nevertheless provides a useful context in which to evaluate IR knowledge creation. Much like studies focused specifically on the field of IR, the report finds uneven internationalization (UNESCO 2010, 143-144), gross inequalities in the production of peer-reviewed articles (Mosbah-Natanson 2010), the hegemonic influence of English (Ammon 2010, 154-155), and disparities in the local capacities to support the social sciences (UNESCO 2010, 99-100). Not surprisingly, the authors argue that, depending on the incentive systems or the structure of funding, local scholars may elect to publish in periodicals in their own language or produce research that is focused on short-term problem-solving as consultants (often to supplement poor salaries) rather than scholastic contributions in ranked peerreviewed journals (UNESCO 2010, 53-54; 350-351).

In terms of scholarly production, the research conducted by Gingras and Mosbah-Natanson (2010) in the UNESCO's report finds that a substantial number of all social science research is produced in North America or Europe. Depending on the database used - Thomson Reuters Social Sciences Citation Index (SSCI) or Ulrich database - North American and European journals make up between about 77 to $90 \%$ of all social science journals published (Ibid., 5 ). Out 
of all the countries that publish journals, the US is by far the first (Ibid., 6). In the Ulrich database English accounts for over 85\% of articles in social science journals, whereas in the SSCI database English accounts for over 94\% (Ibid., 6). In a similar vein, statistical analysis of citations by region showed that, generally speaking, citations of North American and European sources were most common, though the relative dominance of either North American or European sources often depended on the specific region the journal was published in (Ibid., 14-15). These results lead the authors to suggest that an overall growth in social science research has mainly benefited scholars situated in North America and Europe who already had a substantial lead in the social sciences (Ibid., 17).

Though Gingras and Mosbah-Natanson's study is focused on the social sciences in general, much of their research reflects the findings on IR as a discipline. The dominance of scholars situated in the US has received special attention. Biersteker concludes that "American International Relations is globally hegemonic" $(2009,309)$ as a result of the volume of work it produces, the reputation of its departments as well as publications, and the global use of the English language. Other studies support this argument based on the dominance of American scholarship in leading IR journals (Aydinli and Mathews 2000; Hellmann 2011; Tickner and Wæver 2009a) and in the reading lists for IR graduate programs (Hagmann and Biersteker 2012). As the various authors stress, this translates into the dominance of certain theoretical orientations, methodological approaches and IR issues over others - and ultimately of ideas about what constitutes 'good IR scholarship.'

For IR scholarship outside of North America and Europe these realities result in huge balance of trade deficits (Aydinli and Mathews 2000; Wæver 1998). IR departments outside the US are consumers of US-published articles and USauthored articles with those publishing outside the US not getting much through to the US. The vast majority of works read and assigned in American IR departments are therefore written by American scholars, in English and with a predominance of certain orientations, and published in American journals (Biersteker 2012). The issue at hand is therefore not merely an American dominance of the discipline, but also the danger that the discipline will institutionalize and legitimate American biases and perspectives.

When scholars from outside the United States and Europe do contribute to journals, they do so often on topics native to their home countries. As Tickner (2013) argues, when scholars outside the West engage the discipline, they are often boxed in by the disciplinary structures of Western IR. They are brought in as local experts, valued for their descriptive research and local expertise and seldom involved in theorizing with a more universal appeal in the discipline. She 
labeled this an "intellectual division of labor that characterizes knowledge-building throughout the world" (Tickner 2013, 627). These finding have led authors to use dependency theory (Alatas 2003; Tickner 2013) to explain the relationships of regions outside the West to that of North America and Europe. Stretching the economic concepts of dependency theory, works produced outside of the West might be thought of as the more "low-value" inputs (based in local knowledge) needed to make the "high-value" theory that is produced in the West (which supposedly has a much more universal appeal) (Alatas 2003; Tickner 2013). However, even as Alatas - a proponent of dependency theory - notes, financial power is not enough to explain the production of social science papers. If this were so, we would expect a greater level of production from countries such as Japan. The actual production of countries like Japan suggests country-specific factors also play a role in the development of IR departments from country to country (Alatas 2003, 605-606).

At least some of the structural power of the US in the field reflects how various national IR departments choose to weigh and value contributions in the discipline's top journals. As Hellmann writes, "the institutional and structural power of U.S. IR is reflected in how IR scholars in other parts relate to it. For IR scholars in Western Europe, Israel, and South Asia, and to a lesser degree in EastCentral Europe and some parts of Latin America, gaining recognition in the United States (i.e., in U.S.-based IR journals in particular) continues to be a crucial element for professional advancement compared with IR scholars elsewhere" (2011, 1299). Thus, the influence of the US and other Western countries should be greater in countries where scholars are required by their institutions to publish in highly-ranked disciplinary journals and less in countries where publications in local journals or periodicals are given equivalent weight. Indeed, as Alatas writes, there is a sense in which the Japanese and German social science establishments, by not gauging success according to publications in Western journals and allowing authors to publish in their native languages, are "opting out of that game" $(2003,606)$.

In a similar vein, Cox and Nossal (2010) have found that national IR programs are growing increasingly independent of one another. They conclude based on a survey of IR scholarship in the Anglo world that "the days of American hegemony in IR are already gone" $(2010,304)$. As they argue, the rift between national IR markets is growing, with scholars from different countries representing different approaches to IR, publishing in different journals and participating in separate discourses. Against this backdrop, Tickner and Wæver emphasize that IR scholarship in these national communities cannot only be seen in relation to the core, but also as free-standing and "as a purposeful, meaningful, and socially rel- 
evant activity, only under conditions different from those in the core" (Tickner and Wæver 2009b, 339).

In terms of East Asian scholars' participation in IR journals, we might expect quite a few of them to at least attempt to publish in journals ranked in the SSCI, especially since the government as well as tenure requirements in countries like South Korea incentivize them to do so (Lee and Lee 2013). Yet the majority of authors from the region present their work mainly in local journals, those published by domestic universities and departments as well as in local non-scholarly publications that aim at a wider audience (Inoguchi 2009, 97). At the same time, the structural power of the US can be seen in South Korea and Taiwan (and to a far lesser degree Japan) in the large number of active scholars with $\mathrm{PhDs}$ from American departments (Ibid., 96). Lee therefore describes the South Korean work in the field as dominated by American influences and as a "testbed for the utility of theories and conceptual tools developed in the United States" (2014, 78; see also Moon and Kim 2002, 56).

\section{RESEARCH DESIGN: ASSESSING CONTRIBUTIONS TO THE SUBJECT OF NORTH KOREA}

In order to assess contributions to mainstream IR on the subject of North Korea, a research design was created that allowed the researchers to answer the following questions:

(1) Which nations and regions are most represented in mainstream IR discourse on the subject of North Korea?

(2) Which nations and regions provide the most inputs (measured as cited papers in mainstream articles) for mainstream IR on the subject of North Korea?

(3) Are there noticeable differences in the citations patterns of scholars from different nations and regions who partake in the mainstream discourse?

(4) Which languages are most represented in the cited works?

(5) Which theories and methods are most represented in mainstream IR works on North Korea?

Answering these questions involved creating a list of the leading journals in the field of IR using indexes such as the 2012 TRIP Survey and Thomson Reuters SSCI. From these top-tier journals, all the articles that addressed the issue of 
North Korea over the last 25 years were collected. These articles were analyzed in terms of the country of the institution the author or authors were affiliated with at the time of the article's publication, the country in which they obtained their $\mathrm{PhD}$ and the language of the article. After that, the academic citations from these articles were examined, and the location of these articles' authors as well as the language of the articles were recorded. Finally, the theoretical orientation of the articles in the top-tiered journals were examined. This research design allowed the reviewers to assess what was published on the subject of North Korea in mainstream IR journals, the national affiliations of authors publishing on the subject, the language used in the publications, what sources were used in the preparation of these articles, and the overall theoretical makeup and diversity of the articles in the top-tier journals.

In the first step, leading journals in the field of IR were chosen in order to assess the participation of scholars in IR on the subject of North Korea. Using the 2012 TRIP Survey, the 20 journals ranked as most influential by the academics participating in the survey were chosen (Maliniak et al. 2012, 52). Additionally, the 20 journals ranked highest (based on their 5-year impact factor) in the 2013 SSCI were chosen. From the resulting list, duplicate entries as well as the non-peer-reviewed journals Foreign Affairs and Foreign Policy were excluded. ${ }^{2}$ This resulted in a list of 29 journals (See Appendix A).

The authors chose to study journals -- rather than classroom curricula or textbooks -- due to their prominent role in the discipline. In the words of Wæver, they are "the most direct measure of the discipline itself" (Wæver 1998, 697). For most scholars they provide a prime venue to present their work and therefore represent the cutting edge of the discipline. Journals furthermore provide an arena for scholars to engage with each other in academic debate and play an important role in the education of the next generation of IR scholars. The focus on the highest ranked journals is due to their perceived (in the case of the TRIP survey) or measured (in case of the SSCI) impact on the academic discourse on North Korea. While the average number of citations for articles in political science journals has been found to be around 5 in 2003 (Samuels 2011), most articles on North Korea from the selected journals were - according to Google Scholar - cited at least 10 times, and over a third of them more than 50 times.

In the second step of our research, articles with a clear focus on North Korea

\footnotetext{
${ }^{2}$ Foreign Affairs and Foreign Policy were excluded for two reasons: first, they contain articles that are not an immediate part of the academic discourse (for example articles written by politicians); second, the articles in these two journals do not list references. Hence, the second part of this study would have had to ignore them.
} 
published in these journals between March 1990 and March 2015 were selected. The key criteria was the term "North Korea" as part of their title or a clear references to North Korea in the abstract. Articles that treated North Korea as a case study for a theoretical argument, as one of several countries in the context of a comparative case study, or in the context of a larger sample were excluded. The only exceptions made were for articles on the state of the Korean peninsula in general. Also excluded were reviews and review essays on books about North Korea. This resulted in a list of 21 articles (see Appendix B).

In order to analyze the academic background against which these articles were written, the authors' names, the country of the institution they were affiliated with at the time of the article's publication and the country in which they obtained their PhD were recorded. Following Aydinli and Mathews (2000), these countries were assigned to one of four groups based on their perceived location in core and periphery. Group 1 consists of the United States, which is often considered the "core" of IR; group 2 of Western Europe, Canada, Israel and Australia, which is considered the "the periphery of the core"; group 3 of Eastern Europe, Russia, India, China, Japan, South Korea and Singapore, which is considered the "core of the periphery" or the semi-periphery; and group 4 which encompasses all other countries and is considered the "periphery."

Table 1. Country Groups

\begin{tabular}{l|l|l|l}
\hline \multicolumn{1}{c|}{ Group 1 } & \multicolumn{1}{c|}{ Group 2 } & \multicolumn{1}{c}{ Group 3 } & \multicolumn{1}{c}{ Group 4 } \\
\hline United States & Western Europe & Eastern Europe & Other Countries \\
\hline & Canada & Russia & \\
\hline & Israel & India & \\
\hline & Australia & China & \\
\hline & & Japan & \\
\hline & & South Korea & \\
\hline & & Singapore & \\
\hline
\end{tabular}

In the third step of our research, the academic articles cited in the initial 21 articles were analyzed. The rationale behind examining the citations of these articles was to understand what academic research underpinned the work published in mainstream IR journals. Once again, this focus stems from the assumption that academic journals provide the prime venue for authors to publish their research and to engage in debate with their peers. This resulted in a list of 328 cited articles. Since many of the mainstream articles referenced the same research, the list contained a number of duplicates. The duplicate articles were allowed to remain 
in the dataset in order to account for their respective weights in influencing the research of the 21 articles from the mainstream journals. For each of the articles cited, the country of the institution the author was affiliated with at the time of publication as well as the publication language were recorded (similar to Wæver $1998,701)$. As an additional part our research, we charted which regional groups (Group 1, 2, 3, or 4) were more or less likely to cite which regional groups. We conducted this analysis under the assumption that scholars from different country groups might showcase different preferences in their citations.

Finally, the original 21 articles in the top-tier journals were coded according to their theoretical orientation or method. An open-coding method was used. First, each researcher read the articles independently of the other and assigned a label to the article based on their own judgments without the benefit of pre-decided categories. The two researchers then compared their classifications and arrived at a consensus on how to label each article. This process was done to assess the relative theoretical and methodological diversity of articles written for top-tier journals.

\section{RESEARCH RESULTS AND DISCUSSION}

\section{AFFILIATION OF AUTHORS FROM TOP-TIER IR JOURNALS}

The 21 articles on North Korea from the top-ranked IR journals were - through collaborations - written by a total of 24 authors. $58 \%$ of these authors were affiliated with an institution in group 1 and thereby the United States, $17 \%$ with one in group 2 and $25 \%$ with one in group 3 . None of the authors was from group 4. While the dominant role of the United States in this distribution is obvious, it is notable that the numbers for group 1 and 2 are significantly lower than in Tickner and Wæver's analysis of leading American journals (2009a, 4), as well as Aydinli and Mathew's analysis of American as well as non-American journals (2000, 302 ). With one exception, all the authors in group 3 were affiliated with an institution in South Korea. This distribution is most likely due to the specific regional relevance of the topic in question. Another noteworthy aspect of the findings is that, with one exception for which no information was available, all authors obtained their PhD in countries that belong either to group 1 or $2.79 \%$ of these degrees were awarded in the United States, the remaining ones either in England or Australia.

\section{AFFILIATION OF REFERENCED ARTICLES}

The 21 initial articles referenced a total of 328 other articles which were written - 
Figure 1. Authors by Country Group - Mainstream Articles

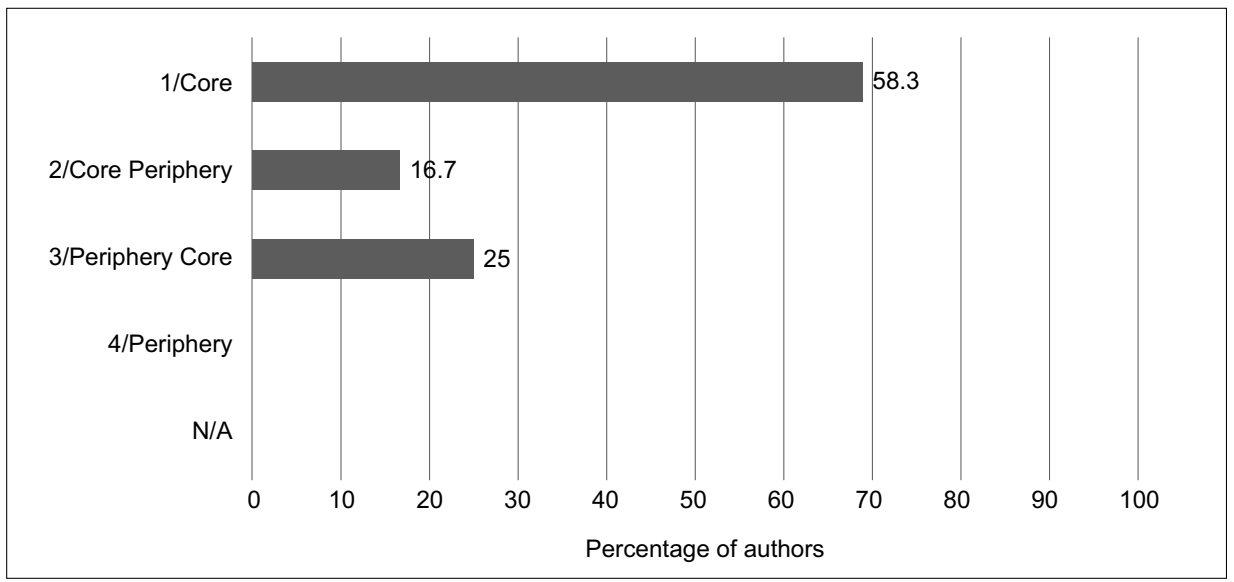

through collaborations - by 421 authors. As was mentioned before, these numbers contain duplicates, hence a number of articles and authors show up multiple times in this list. Of the authors referenced in the initial set of articles, two thirds were affiliated with an institution in group 1 at the time of the article's publication. A further $19 \%$ were affiliated with an institution in group 2, 14\% in group 3 and less than $1 \%$ in group 4 . In two cases it was not possible to determine the author's institutional affiliation at the time of publication.

Figure 2. Authors by Country Group - Referenced Articles

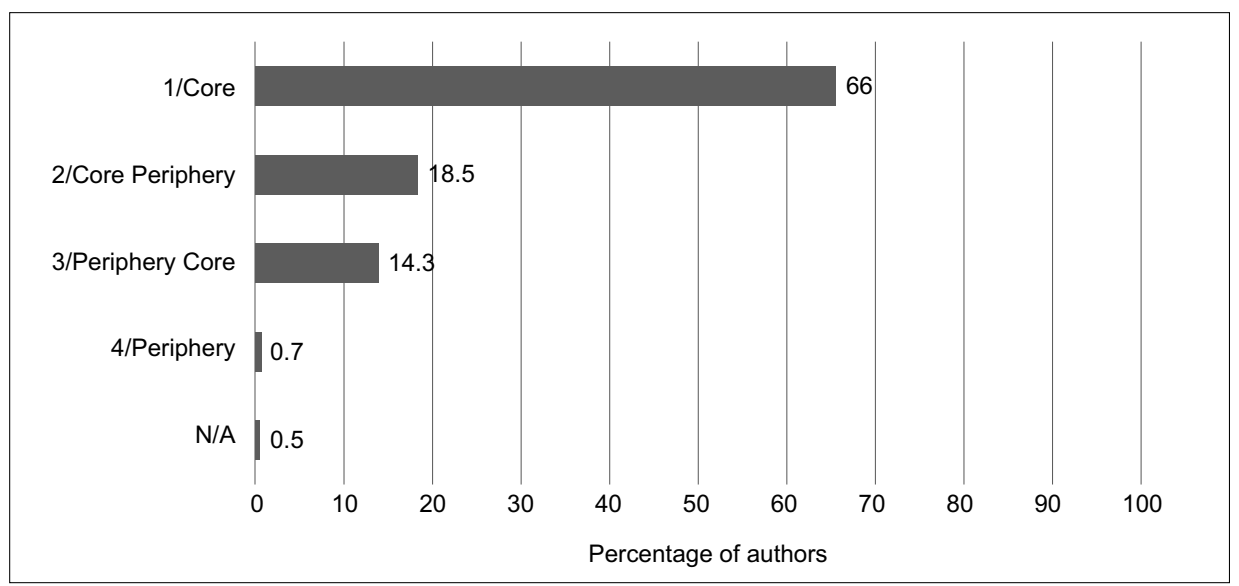


It is noteworthy that the distribution of references over the groups changes depending on the group that the author(s) of the initial article belong(s) to. Mainstream articles written by authors affiliated with an institution in group 1 reference predominantly authors who also belong to group 1, that is authors who are affiliated with an institution in the United States. Only $12 \%$ and $10 \%$ respectively of the articles referenced in mainstream articles written by authors from group 1 belong to group 2 and 3 , with $1 \%$ belonging to group 4 . Among the mainstream articles written by authors from group 2 and 3 , the distribution of references over the first three groups is more even, although the largest share of references still points at authors belonging to group 1; no references by authors from group 2 and 3 point to group 4 .

These results support the findings of other studies. Hagmann and Biersteker observed a "self-referential American practice" (2012, p. 303) in the selection of materials for IR teaching. Yet, as Tickner emphasizes, these observations have to be seen in the context of the American "control over the intellectual means of production in IR" (2013, 634). The United States hosts the most IR departments, faculty members and students in the field of any country. This dominance in numbers is illustrated by the participants in the TRIP study, more than half of which are situated in the US. Nevertheless, it is notable that the distribution of references over the four groups differs significantly depending on the region in which the author is situated.

Figure 3. Who Cites Whom

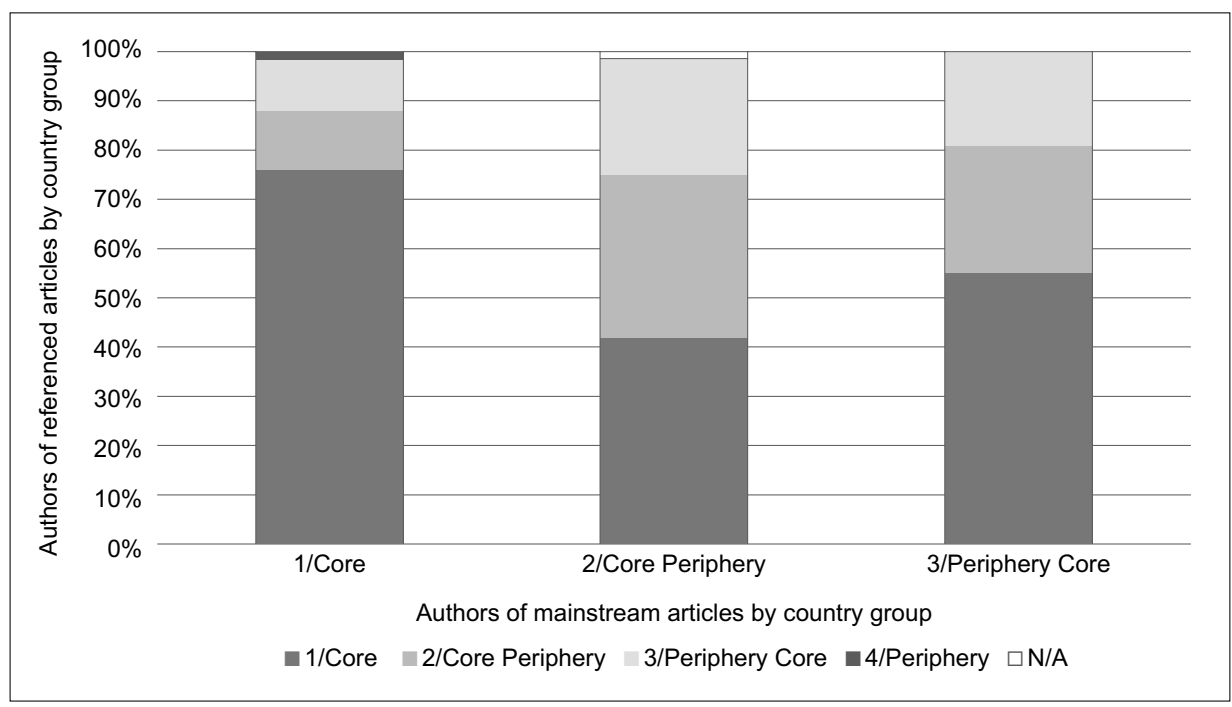




\section{LANGUAGES OF JOURNAL PUBLICATIONS}

It is noteworthy that of the 328 referenced journal articles $99 \%$ were written in English. The three exceptions are one French article as well as two Korean articles, the latter of which were both quoted in the same article by authors situated in South Korea. As must be emphasized, these numbers only take into account articles in academic journals. A number of the initial 21 articles reference newspaper reports, books and research reports in Korean and Chinese; these are not part of the data presented here. Nevertheless, these numbers show a language divide which apparently separates the research published in English-language journals from that published in journals of other languages. Even in the case of an issue of regional relevance such as North Korea, research that is not written in English apparently does not feature in the leading journals' contributions.

Without further - and especially qualitative - inquiry it is difficult to interpret the origins of this phenomenon. It may be that academic journal articles written in languages other than English are ignored for a number of reasons. These reasons could include (but may not be limited to): a lack of language ability on the part of scholars; the perception that research published in English is of superior quality; the relative small number of non-English language peer-reviewed studies; the preferences of scholars writing in other languages to use non-peer reviewed publishing options; or an inability to access databases that catalog journals in other languages. The data from the TRIP survey is inconclusive in this regard. As the 2012 iteration found, 39\% of the participating scholars from the United States can conduct research in more than one language, and 31\% in at least two additional languages. Nevertheless, only $27 \%$ of US scholars "regularly" rely on research in a language not written in their native one (Maliniak et al. 2012, 42). Similar to what research on other regions of the world has found - for example, Hanafi's study of IR in the Arabic language sphere (2011, 295) - the findings from our study suggest that Korean-language scholarship may exist as its own autonomous sphere, relevant within its own debates but with little impact on the wider international discourse. 
Figure 4. Referenced Articles by Language

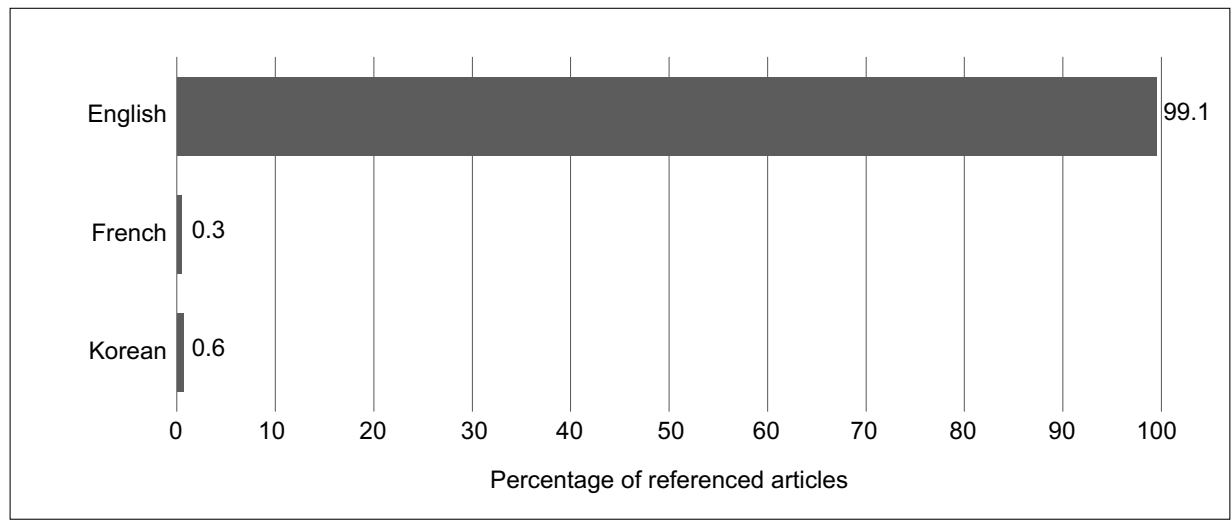

\section{THEORETICAL PERSPECTIVE OF ARTICLES}

With few exceptions, the articles in this sample were not explicitly theoretical. Rarely did any article state a particular paradigm or engage in an inter-paradigm or meta-theoretical debate. Thus, the categories were more implicit and had to be teased out of the text. The authors independently coded the articles and then reached an agreement about which codes best fit the articles. These codes, however, should be seen as rough estimates. The fact that many of the articles do not specifically engage in theoretical debates may signify that the theoretical issues were deemed secondary to the analysis at hand. In at least three cases, studies engaged very particular forms of theory: sanctions theory, authoritarian control theory, and deterrence theory. These theories could be defined as situated within a larger sphere of non-formalized or "soft" rational choice.

Amongst the articles, even when methods differed - case study, quantitative analysis, discourse analysis - most authors shared similar theoretical assumptions that were largely implicit. These shared assumptions for the most part combined elements of soft-rationalism and non-postmodern constructivism. This theoretical grounding is broadly consistent with what has been found in the 2012 TRIP survey of IR scholarship, where a substantial number of scholars across many different countries answered that they employed a loose version of rational choice or did not assume the rationality of their actors at all (Maliniak et al. 2012, 26), and where the greatest percentage of respondents stated that they conduct "policy analysis" (Ibid., 34). It is also consistent with data from the survey that shows large numbers of scholars are either "constructivist" in approach or do not use any paradigmatic analysis in their research (Ibid., 26). 
Table 2. Theoretical Perspective by Article

\begin{tabular}{|c|c|}
\hline Article Title & Theoretical Perspective \\
\hline $\begin{array}{l}\text { Pyongyang's Survival Strategy: Tools of Authoritarian Control in North } \\
\text { Korea }\end{array}$ & $\begin{array}{l}\text { Authoritarian Control } \\
\text { Empirical Analysis }\end{array}$ \\
\hline $\begin{array}{l}\text { Why Not Invade North Korea? Threats, Language Games, and U.S. } \\
\text { Foreign Policy }\end{array}$ & Constructivism \\
\hline $\begin{array}{l}\text { Entrenching 'identity norms' of tolerance and engagement: lessons from } \\
\text { rapprochement between North and South Korea }\end{array}$ & Constructivism \\
\hline $\begin{array}{l}\text { A Rogue is a Rogue is a Rogue: US Foreign Policy and the Korean } \\
\text { Nuclear Crisis }\end{array}$ & $\begin{array}{l}\text { Constructivism } \\
\text { Balance of Threat Theory }\end{array}$ \\
\hline North Korea and the 'Madman' Theory & $\begin{array}{l}\text { Constructivism } \\
\text { Soft-Rational Choice }\end{array}$ \\
\hline Preventive War and North Korea & Deterrence Theory \\
\hline International Relations Theory and the Second Korean War & $\begin{array}{l}\text { Deterrence Theory } \\
\text { Theory Evaluation }\end{array}$ \\
\hline Hawk Engagement and Preventive Defense on the Korean Peninsula & Foreign Policy Analysis \\
\hline North Korea's Arduous Trip: The North-South Summit Examined & Historical / Case Study \\
\hline Going Just a Little Nuclear: Nonproliferation Lessons from North Korea & Historical / Case Study \\
\hline $\begin{array}{l}\text { North Korea after Kim II-Song and the Future of North-South Korean } \\
\text { Relations }\end{array}$ & $\begin{array}{l}\text { Historical } \\
\text { Case Study }\end{array}$ \\
\hline $\begin{array}{l}\text { Bad, Mad, Sad or Rational Actor? Why the 'Securitization' Paradigm } \\
\text { Makes for Poor Policy Analysis of North Korea }\end{array}$ & $\begin{array}{l}\text { Implicit Constructivism } \\
\text { Soft-Rational Choice }\end{array}$ \\
\hline Security on the Korean Peninsula: Continuity and Change & Implicit Realism \\
\hline Illicit Activity and Proliferation: North Korean Smuggling Networks & IPE Case Study \\
\hline North Korea: Market Opportunity, Poverty and the Provinces & IPE Case Study \\
\hline The economic geography of North Korean drug trafficking networks & IPE Case Study \\
\hline The Collapse of North Korea: Military Missions and Requirements & $\begin{array}{l}\text { Policy Planning } \\
\text { Policy Recommendation }\end{array}$ \\
\hline The North/South Korea Boundary Dispute in the Yellow (West) Sea & Policy Recommendation \\
\hline Integrative Complexity of South-north Korean Correspondences & Quantitative Study \\
\hline $\begin{array}{l}\text { Rewarding North Korea: Theoretical Perspectives on the } 1994 \text { Agreed } \\
\text { Framework }\end{array}$ & $\begin{array}{l}\text { Sanctions Theory } \\
\text { Theory Evaluation }\end{array}$ \\
\hline $\begin{array}{l}\text { Stopping a North Korean Invasion: Why Defending South Korea Is Easier } \\
\text { than the Pentagon Thinks }\end{array}$ & Strategic Analysis \\
\hline
\end{tabular}

\section{CONCLUSION}

In regard to the questions posed at the outset, the results of this study reinforce what other scholars have argued about the IR discipline. Even on a topic such as 
North Korea, which one might expect to be of special relevance for scholars from the region, a disproportionate share of the work published in mainstream journals is produced first and foremost in the United States, with some participation from writers in South Korea, the wider Asia-Pacific and Western Europe. Contrary to what one might expect, local scholars have a relatively marginal impact even on the mainstream IR discourse concerned with specific regions beyond the core. Furthermore, as our research shows, the authors who published on North Korea in these mainstream journals were educated in a small number of countries and showcase virtually no engagement with academic articles written in languages other than English. Thus, we are left with the question of whether the research published in mainstream journals on region-specific topics such as North Korea exhibits core-specific biases - and whether it would look different if the voices of scholars from other regions were more pronounced.

The mainstream articles studied here predominantly share a common framework of soft-rationalism and non-postmodern constructivism that privileges theory deepening, engagement with popular ideas about North Korea outside of the IR field and descriptive research. Though a more inclusive group of scholars would surely help the subfield, the authors find that the common grounding of these articles is essentially a positive development. This grounding largely comports with the worldview of scholars and practitioners outside the scholarly confines of IR. Moreover, the scholarship was mostly written in such a way as to provide easy access for policymakers.

The growing literature that questions the American and European dominance of the discipline and espouses a post-Western IR theory has proposed that a more inclusive discipline will create a richer ecosystem of thought. Yet, one must still be cautious about simple assumptions that diversity of nationalities and institutions will lead to diverse kinds of research. As past studies (Bilgin 2008; Ikeda 2010; Tickner and Blaney 2009) have demonstrated, scholarship produced outside of the core or by non-core authors residing within the West does not necessarily produce alternatives to mainstream IR. A richer field of study, however, might benefit from a shared theoretical grounding of soft-rational choice and non-postmodern constructivism that is simultaneously implied rather than explicit, practical rather than esoteric, yet flexible enough to encompass a wide range of studies, methods and contributions. In this way, contributions may fit into a paradigm of study espoused by Sil and Katzenstein (2010) termed "Analytical Eclecticism" which privileges pragmatic question-probing and real world problem-solving over meta-theoretical debates and paradigm competition.

A trend toward eclectic but pragmatic scholarship might naturally draw in scholars and researchers who are, at the moment, opting out of mainstream IR 
journals. Indeed, one of the most plausible explanations for why American and European scholars continue to dominate mainstream IR is because scholars in other countries are choosing local academic and non-academic markets over journals published in America and Europe. This explanation is consistent with scholarship by Aydinli and Mathews (2000) that argues that IR is still very much a parochial discipline, with Americans dominating top-tier journals in their own country and IR scholars elsewhere choosing to publish in markets closer to home. It may very well be that the field of knowledge on North Korea is more diverse than would first appear but that this scholarship is published "parochially" with South Korean scholars choosing to publish in South Korean journals, Japanese preferring to publish in Japanese journals, and so on.

This also fits with conclusions made by the UNESCO World Social Science Report that social science talent outside the West is often used to address local, short-term problems through think tanks, other consultancy-based research, or contributions through magazine and newspaper articles (UNESCO 2010, 53-54, 350-351). This same tendency may apply to social science departments in the semi-periphery that have recently developed greater capacities for research. As Inoguchi (2009) points out, a remarkable amount of social science research in countries like Taiwan, Japan and South Korea is done for government consumption either through think tanks or scholarship sponsored by the government. Our study has chosen to skip over this knowledge production in favor of exploring contributions to the field of IR through peer-reviewed publications in scholarly journals. Different patterns could be expected to emerge if think tank research were examined.

Thus, the limitations of our study point to various questions that future studies could explore. These studies could examine the publishing patterns of journals that are outside the discipline's mainstream, focusing on specific regions, or journals that publish in languages other than English. Future studies could furthermore take a qualitative approach and ask, similar to Hanafi (2011), how local scholars chose the outlets and languages in which they publish. Such knowledge could be valuable for editors looking to entice a more diverse range of scholars to contribute to their journals. These studies could also explore the inverse of these questions: instead of asking how local scholars impact the discipline of IR, they could also ask how IR has impacted local discourses on the subject, and how it has been used by local think tanks and government research institutions for their own purposes. These different perspectives might help to further illuminate knowledge production within IR, and especially so with a focus on topics and scholars that are commonly seen as part of the periphery. 


\section{REFERENCES}

Acharya, Amitav and Barry Buzan. 2007. "Why Is There No Non-Western International Relations Theory?” International Relations of the Asia Pacific 7(3), 287-312.

Alatas, Syed Farid. 2003. "Academic Dependency and the Global Division of Labour in the Social Sciences." Current Sociology 51(6), 599-613.

Ammon, Ulrich. 2010. "The hegemony of English." In UNESCO. ed. World Social Science Report 2010: Knowledge Divides, Paris: International Social Science Council, UNESCO, 154-155.

Aydinli, Ersel and Julie Mathews. 2000. "Are the Core and Periphery Irreconcilable? The Curious World of Publishing in Contemporary International Relations." International Studies Perspectives 1(3), 289-303.

Biersteker, Thomas J. 2009. "The parochialism of hegemony: challenges for ‘American' International Relations.” In Arlene B. Tickner and Ole Wæver. eds. International Relations Scholarship around the World, London: Routledge, 308-327.

Bilgin, Pinar. 2008. “Thinking Past ‘Western’ IR.” Third World Quarterly 29(1), 5-23.

Cox, Wayne S. and Kim Richard Nossal. 2010. "The 'crimson world': the Anglo core, the post-Imperial non-core, and the hegemony of American IR.” In Arlene B. Tickner and Ole Wæver. eds. International Relations Scholarship around the World, London: Routledge, 287-307.

Gingras, Yves and Sébastien Mosbah-Natanson. 2010. "Background Paper: Where are the social sciences produced?” In UNESCO. ed. World Social Science Report 2010 - Knowledge Divides, Paris: International Social Science Council, UNESCO. Accessed at http://unesdoc.unesco.org/ images/o019/001906/190656E.pdf (11 October, 2015).

Hagmann, Jonas and Thomas J. Biersteker. 2012. "Beyond the published discipline: Towards a critical pedagogy of international studies.” European Journal of International Relations 20(2), 291-315.

Hanafi, Sari. 2011. "University systems in the Arab East: Publish globally and perish locally vs publish locally and perish globally." Current Sociology 59(3), 291-309.

Hellmann, Gunther. 2011. "International Relations as a Field of Study." In Bertrand Badie, Dirk Berg-Schlosser and Leonardo Morlino. eds. International Encyclopedia of Political Science, Thousand Oaks, CA: Sage, 1298-1316.

Hoffmann, Stanley. 1977. "An American Social Science: International Relations.” 
Daedalus 106(3), 41-60.

Ikeda, Josuke. 2010. "The Post-Western Turn in International Theory and the English School." Ritsumeikan Annual Review of International Studies 9, 29-44.

Inoguchi, Takashi. 2009. "Japan, Korea, and Taiwan: are one hundred flowers about to blossom?” In Arlene B. Tickner and Ole Wæver. eds. International Relations Scholarship around the World, London: Routledge, 86-102.

Lee, Geun. 2014. "European Influence on International Relations Studies in Korea." European Review of International Studies 1(1), 70-79.

Lee, Hikyoung and Kathy Lee. 2013. "Publish (in international indexed journals) or perish: Neoliberal ideology in a Korean university." Language Policy 12(3), 215-230.

Maliniak, Daniel, Susan Peterson, and Michael J. Tierney. 2012. TRIP around the world: Teaching, research, and policy views of International Relations faculty in 20 countries. The Institute for the Theory and Practice of International Relations, The College of William and Mary. Accessed at https://www.wm.edu/offices/itpir/_documents/trip/trip_around_the _world_2011.pdf (11 October, 2015).

Moon, Chung-In and Taehwan Kim. 2002. "International Relations Studies in South Korea.” Journal of East Asian Studies 2(1), 45-68.

Ofuho, CirinoHiteng. 2009. "Africa: teaching IR where it's not supposed to be." In Arlene B. Tickner and Ole Wæver ed., International Relations Scholarship around the World, London: Routledge, 71-85.

Samuels, David J. 2011. "The Modal Number of Citations to Political Science Articles Is Greater than Zero: Accounting for Citations in Articles and Books." PS: Political Science \& Politics 44(4), 783-792.

Sil, Rudra and Peter J. Katzenstein. 2010. Beyond Paradigms: Analytic Eclecticism in the Study of World Politics. London: Palgrave.

Smith, Steve. 2000. "The discipline of international relations: still an American social science?" The British Journal of Politics \& International Relations 2(3), 374-402.

Tan, See Seng. 2009. "Southeast Asia: theory and praxis in International Relations.” In Arlene B. Tickner and Ole Wæver. eds. International Relations Scholarship around the World, London: Routledge, 120-133.

Tickner, Arlene B. and David L. Blaney. 2009. "Introduction: thinking difference." In Arlene B. Tickner and David L. Blaney. eds. Thinking International Relations Differently, London: Routledge, 1-24.

Tickner, Arlene B. and Wæver, Ole. 2009a. "Introduction: geocultural epistemologies.” In Arlene B. Tickner and Ole Wæver. eds. International 
Relations Scholarship around the World, London: Routledge, 1-31. . 2009b. "Conclusion: worlding where the west once was." In Arlene B. Tickner and Ole Wæver. eds. International Relations Scholarship around the World, London: Routledge, 328-341.

Tickner, Arlene B. 2013. "Core, periphery and (neo)imperialist International Relations." European Journal of International Relations 19(3), 627-646. UNESCO (ed.). 2010. World Social Science Report 2010: Knowledge Divides. Paris: International Social Science Council, UNESCO.

Wæver, Ole. (1998). "The Sociology of a Not So International Discipline: American and European Developments in International Relations." International Organization 52(4), 687-727.

[Received October 15, 2015; Revised December 1, 2015; Accepted December 5, 2015] 


\section{Appendix 1. List of Journals}

$\square$ International Organization

$\square$ International Studies Quarterly

$\square$ International Security

$\square$ American Political Science Review

$\square$ World Politics

$\square$ European Journal of International Relations

$\square$ Journal of Conflict Resolution

$\square$ Review of International Studies

$\square$ Millennium

$\square$ American Journal of Political Science

$\square$ International Affairs

$\square$ Security Studies

$\square$ Review of International Political Economy

$\square$ Journal of Peace Research

$\square$ International Studies Review $\square$ International Relations

$\square$ Comparative Politics

$\square$ Global Governance

$\square$ Marine Policy

$\square$ Security Dialogue

$\square$ International Political Sociology

$\square$ New Political Economy

$\square$ Common Market Law Review

$\square$ Journal of Common Market Studies

$\square$ Biosecurity and Bioterrorism

$\square$ Review of Political Economics

$\square$ Review of International Organizations

$\square$ International Journal of Transitional Justice

$\square$ Review of World Economics

\section{Appendix 2. Articles from Top-Ranked IR Journals}

\begin{tabular}{l|l}
\hline Title & Authors(s) \\
\hline The economic geography of North Korean drug trafficking networks & Justin V. Hastings \\
\hline $\begin{array}{l}\text { North Korea after Kim II-Song and the Future of North-South Korean } \\
\text { Relations }\end{array}$ & Kim Hakyoon \\
\hline $\begin{array}{l}\text { Entrenching 'identity norms' of tolerance and engagement: lessons from } \\
\text { rapprochement between North and South Korea }\end{array}$ & Key-Young Son \\
\hline Security on the Korean Peninsula: Continuity and Change & Young Whan Kihl \\
\hline North Korea: Market Opportunity, Poverty and the Provinces & Hazel Smith \\
\hline $\begin{array}{l}\text { Integrative Complexity of South-north Korean Correspondences } \\
\text { Preventive War and North Korea }\end{array}$ & $\begin{array}{l}\text { Jasook Koo } \\
\text { Junghyun Kim }\end{array}$ \\
\hline North Korea and the 'Madman' Theory & David C. Kang \\
\hline $\begin{array}{l}\text { The Collapse of North Korea: Military Missions and Requirements } \\
\text { Framework }\end{array}$ & $\begin{array}{l}\text { Denny Roy } \\
\text { Jennifer Lind }\end{array}$ \\
\hline $\begin{array}{l}\text { The North/South Korea Boundary Dispute in the Yellow (West) Sea } \\
\text { Curtis H. Martin }\end{array}$ & $\begin{array}{l}\text { Jon M. Van Dyke } \\
\text { Jenny Miller Garmendia }\end{array}$ \\
\hline
\end{tabular}


TheK orean J ournal of International Studies 13- 3 | 534

\begin{tabular}{l|l}
\hline Title & Authors(s) \\
\hline $\begin{array}{l}\text { Why Not Invade North Korea? Threats, Language Games, and U.S. } \\
\text { Foreign Policy }\end{array}$ & Peter Howard \\
\hline $\begin{array}{l}\text { A Rogue is a Rogue is a Rogue: US Foreign Policy and the Korean } \\
\text { Nuclear Crisis }\end{array}$ & Roland Bleiker \\
\hline $\begin{array}{l}\text { Bad, Mad, Sad or Rational Actor? Why the 'Securitization' Paradigm } \\
\text { Makes for Poor Policy Analysis of North Korea }\end{array}$ & Hazel Smith \\
\hline $\begin{array}{l}\text { Stopping a North Korean Invasion: Why Defending South Korea Is Easier } \\
\text { than the Pentagon Thinks }\end{array}$ & Michael O'Hanlon \\
\hline $\begin{array}{l}\text { Illicit Activity and Proliferation: North Korean Smuggling Networks } \\
\text { International Relations Theory and the Second Korean War }\end{array}$ & Sheena Chestnut \\
\hline $\begin{array}{l}\text { Pyongyang's Survival Strategy: Tools of Authoritarian Control in North } \\
\text { Korea }\end{array}$ & $\begin{array}{l}\text { Daniel Byman } \\
\text { Jennifer Lind }\end{array}$ \\
\hline Going Just a Little Nuclear: Nonproliferation Lessons from North Korea & Michael J. Mazarr \\
\hline Hawk Engagement and Preventive Defense on the Korean Peninsula & Victor D. Cha \\
\hline North Korea's Arduous Trip: The North-South Summit Examined & Jaeho Hwang \\
\hline
\end{tabular}

